\title{
Peningkatan Pemahaman Konsep Tentang Bagian Tumbuhan melalui Media Audio Visual pada Siswa Kelas IV SD Negeri 3 Menawan
}

\author{
Ayu Alfiani \\ SD Negeri 3 Menawan \\ ayualfiafio@gmail.com
}

\section{Article History}

accepted 14/11/2020

approved 21/11/2020

published 26/11/2020

\begin{abstract}
Lack of students' understanding of a learning concept can be related to the choice of media in learning activities. The use of audio-visual media can display real objects as well as parts that are difficult to present directly in a short time and played repeatedly to improve students' understanding of learning concepts in large and small groups. This type of research is Classroom Action Research (PTK). The stages carried out in this study include planning, implementing actions and observations, as well as reflection which are carried out in two cycles. This research was conducted on fourth grade students of SD Negeri 3 Menawan, Klambu district, Grobogan district. The results of the study were indicated by the percentage of student learning outcomes that had increased by $13 \%$. In the first cycle it was $67 \%$, while in the second cycle it became $80 \%$ and there was an increase in the average score of students from 70 to 75 . This shows that the use of audio-visual media can improve understanding of the concept of plant parts, especially in grade IV SDN 3 Menawan.
\end{abstract}

Keywords: media, learning concept, audio visual media

\begin{abstract}
Abstrak
Kurangnya pemahaman siswa mengenai sebuah konsep pembelajaran dapat berkaitan dengan pemilihan media dalam kegiatan pembelajaran. Penggunaan Media audio visual dapat menampilkan obyek nyata maupun bagian yang sulit untuk dihadirkan langsung dalam waktu singkat dan diputar secara berulang-ulang guna meningkatkan pemahaman konsep belajar siswa dalam kelompok besar maupun kecil. Jenis penelitian ini yaitu Penelitian Tindakan Kelas (PTK). Tahapan-tahapan yang dilakukan dalam penelitian ini meliputi perencanaan, pelaksanaan tindakan dan observasi, serta refleksi yang dilakukan dalam dua siklus. Penelitian ini dilaksanakan pada siswa kelas IV SD Negeri 3 Menawan kecamatan Klambu kabupaten Grobogan. Hasil penelitian ditunjukkan dengan persentase ketuntasan hasil belajar siswa yang mengalami peningkatan sebanyak $13 \%$. Pada siklus I $67 \%$, sedangkan pada siklus II menjadi $80 \%$ serta adanya peningkatan nilai rata-rata siswa dari semula 70 menjadi 75 . Hal ini menunjukkan bahwa penggunaan media audio visual dapat meningkatkan pemahaman konsep mengenai bagian tumbuhan khususnya pada siswa kelas IV SDN 3 Menawan.
\end{abstract}

Kata kunci: media, pemahaman konsep, media audio visual

Social, Humanities, and Education Studies (SHEs): Conference Series https://jurnal.uns.ac.id/shes

p-ISSN 2620-9284

e-ISSN 2620-9292 


\section{PENDAHULUAN}

Pendidikan merupakan hal yang penting karena pendidikan adalah akar dari peradaban sebuah bangsa. Pendidikan sekarang telah menjadi kebutuhan pokok yang harus dimiliki setiap orang agar bisa menjawab tantangan kehidupan. Pendidikan di Indonesia terus berkembang demi terwujudnya tujuan pendidikan sebagaimana telah tertera pada pengertian pendidikan agar peserta didik secara aktif dapat mengembangkan potensi dirinya untuk memiliki kekuatan spiritual keagamaan, pengendalian diri, kepribadian, kecerdasan, akhlak mulia, serta keterampilan. Dewasa ini dunia pendidikan di Indonesia telah mengalami perkembangan yang sangat pesat. Hal ini disebabkan oleh upaya pemerintah untuk terus memperbaiki mutu pendidikan di Indonesia. Pemerintah terus berupaya meningkatkan sarana fisik maupun nonfisik yang dapat menunjang optimalnya proses pembelajaran.

Penerapan kurikulum 2013 memerlukan perubahan paradigma pembelajaran, dimana peserta didik dilatih untuk belajar mengobservasi, mengajukan pertanyaan, mengumpulkan data, menganalisis (mengasosiasikan) data, dan mengkomunikasikan hasil belajar yang disebut pendektan saintifik. Namun sering kali peserta didik memiliki kesulitan dalam mengikuti proses pembelajaran terutama pada masa pandemi Covid-19 yang terjadi saat ini.

Proses pembelajaran daring di masa pandemi ini menimbulkan banyak dampak pada dunia pendidikan di Indonesia. Pembelajaran tatap muka tidak dapat dilaksanakan. Guru dan siswa terbatasi oleh jarak dan waktu. Pelayanan pendidikan dari pendidik kepada peserta didik mengalami banyak hambatan. Seringkali guru dengan keterbatasan kemampuan teknologi dan sarana prasarana di sekitar peserta didik yang kurang mendukung menyebabkan berkurangnya aktifitas belajar sehingga minat belajar menurun dan kemampuan menerima penanaman konsep tidak tercapai dengan baik.

Berkurangnya interaksi dalam kegiatan pembelajaran secara tatap muka tidaklah seharusnya mengurangi tercapainya tujuan pendidikan. Karenanya guru tetap dituntut melaksanakan kegiatan pembelajaran bersama peserta didik meskipun kegiatan tersebut dilakanakan dalam jaringan. Kebiasaan baru ini menuntut guru dan siswa untuk melek terhadap teknologi. Penggunaan berbagai platform dalam kegiatan pembelajaran dipercaya mampu membantu guru dan siswa dalam kegiatan pembelajaran. Menghadapi hal ini, tentunya seorang guru harus meningkatkan kemampuannya dalam menggunakan aplikasi berbasis teknologi. Guru dituntut kreatif dalam memilih media dalam rangka meningkatkan pemahaman siswa terhadap sebuah konsep.

Kenyataan yang dijumpai adalah dalam proses pembelajaran yang dilaksanakan secara daring, seringkali ditemukan kesulitan yaitu berkaitan dengan kondisi sarana dan prasarana terlebih pembelajaran daring ini membutuhkan perangkat dan jaringan yang memadai. Pembelajaran daring yang dilaksanakan yaitu secara sinkronus maupun asinkronus. Pembelajaran secara sinkronus dilaksanakan dalam rangka membantu siswa dalam memberikan bimbingan dan motivasi kepada siswa serta mengetahui interaksi siswa dan kesulitan yang dialami siswa. Sedangkan pembelajaran asinkronus dilaksanakan dalam rangka pengumpulan tugas, pengiriman link akses media serta materi dan lembar kerja peserta didik.

Hasil dari pembelajaran daring yang telah dilakukan menunjukkan siswa masih kurang memahami konsep materi dari penjelasan yang diberikan oleh guru, siswa pasif dalam KBM daring dan hasil evaluasi pembelajaran siswa rendah. Salah satu komponenn penting dalam pembelajaran yaitu penggunaan media. Pemilihan media penting untuk dilakukan oleh seorang guru karena media merupakan alat bantu dalam menyampaikan pesan ataupun memberikan pemahaman siswa 
terhadap suatu pengetahuan maupun obyek. Suatu pemahaman terhadap konsep akan lebih tepat jika disampaikan melalui media yang sesuai dengan karakteristik peserta didik jaman sekarang dimana pada umumnya peserta didik yang kerap disebut generasi $Z$ tertarik dengan media yang dapat ditangkap oleh indera pendengaran dan penglihatan atau sering disebut media audio visual seperti video atau film. Maka untuk mengatasi hal ini, diharapkan penggunaan media audio visual mampu menarik perhatian siswa serta memudahkan siswa memahami konsep materi. Disamping itu guru juga harus aktif dalam pembelajaran daring dalam memotivasi siswa supaya aktif dalam pembelajaran daring. Penggunaan media audio visual ini juga dapat mengkonkretkan konsep materi IPA tentang bagian tumbuhan sehingga pemahaman siswa meningkat. Dari uraian yang telah dijabarkan, maka peneliti ingin melakukan penelitian dan peningkatan ttentang pemahaman konsep bagian tumbuhan pada siswa.

\section{METODE}

Penelitian ini menggunakan penelitian tindakan kelas yang merupakan tindakan reflektif oleh peneliti untuk meningkatkan pemahaman konsep siswa mengenai bagian tumbuhan. PTK ini dilaksanakan dua siklus di SD Negeri 3 Menawan, kecamatan Klambu, kabupaten Grobogan. Subjek penelitian adalah guru dan siswa kelas IV dengan jumlah 15 siswa yang terdiri dari 4 siswa laki-laki dan 11 siswa perempuan. Pemilihan subjek ini karena dijumpai permasalahan sebelumnya, yaitu guru hanya menggunakan whatsapp grup dan belum menggunakan media pembelajaran audio visual serta kurangnya pemahaman konsep siswa mengenai bagian tumbuhan.

\section{HASIL DAN PEMBAHASAN}

Pada siklus I, yang dilaksanakan pada tanggal 2 November 2020 peneliti melaksanakan pembelajaran secara sinkronus dan asinkronus. Pembelajaran secara sinkronus dilaksanakan melalui zoomcloudmeeting dan menggunakan media audio visual berupa video. Pembelajaran asinkronus dilaksanakan melalui whatsapp grup maupun google form. Dari hasil penelitian, diperoleh data hasil evaluasi kognitif siswa, sebagai berikut

Tabel.1 DAFTAR HASIL EVALUASI SIKLUS 1

\begin{tabular}{rlccl}
\hline No. & Nama Siswa & KKM & Nilai & Keterangan \\
\hline 1 & Arfa Yuana Putra & 70 & 70 & Tuntas \\
2 & Aprilia Suci R. & 70 & 60 & Belum Tuntas \\
3 & Ayu Rosalinda & 70 & 70 & Tuntas \\
4 & Banun Maulida & 70 & 80 & Tuntas \\
5 & Biha Zidta Saqina & 70 & 70 & Tuntas \\
6 & Bilqis Safiqa & 70 & 80 & Tuntas \\
7 & Candra Andrea Dhiyaksa & 70 & 90 & Tuntas \\
8 & Fanisya Sya'baniyah & 70 & 60 & Belum Tuntas \\
9 & Layyina Qurotun Aini & 70 & 80 & Tuntas \\
10 & Muhammad Bahrul Alam & 70 & 60 & Belum Tuntas \\
11 & Muhammad llyas Abdullah & 70 & 40 & Belum Tuntas \\
12 & Najwa Ainun Niswa & 70 & 80 & Tuntas \\
13 & Rossalina Arsyil Al Arifi & 70 & 80 & Tuntas \\
14 & Sekha Nur Rohmah & 70 & 60 & Belum Tuntas
\end{tabular}


15 Tri Aulia

Rata-rata

Nilai tertinggi

Nilai Terendah

Siswa Tuntas

Siswa Tidak Tuntas

Persentase Ketuntasan
$70 \quad 70 \quad$ Tuntas

70

90

40

10

5

$67 \%$

Dari tabel di atas, diperoleh data nilai evaluasi kognitif siswa dengan presentase ketuntasan sebesar 67\%, dimana nilai tertinggi yaitu 90 dan nilai terendah 40 . Sebanyak 5 siswa belum tuntas, dan 10 siswa tuntas dengan KKM 70. Presentase ketuntasan yaitu $67 \%$.

Kemudian dari tabel di atas peneliti mengolah data hasil ke dalam interval nilai yang dituangkan ke dalam tabel berikut:

Tabel 2. Rentang nilai hasil belajar peserta didik

\begin{tabular}{lll}
\hline Rentang Nilai & Jumlah peserta didik & Persentase (\%) \\
\hline $80-100$ & 6 orang & $40 \%$ \\
$60-79$ & 8 orang & $53,33 \%$ \\
$40-59$ & 1 orang & $6,67 \%$ \\
$<40$ & - & $0 \%$ \\
Jumlah & 15 orang & $100 \%$
\end{tabular}

Dari data tersebut diperoleh rentang hasil evaluasi siklus I sebanyak $40 \%$ siswa mendapatkan nilai $80-100,53,33 \%$ ada pada rentang nilai $60-79$, sisanya sebanyak $6,67 \%$ mendapat nilai pada rentang 40-59 dan tidak ada yang siswa yang mendapatkan nilai rentang di bawahnya.

Data yang diperoleh dari siklus I digunakan untuk refleksi dan merencanakan penelitian siklus II. Siklus II dilaksanakan tanggal 9 November 2020 dengan menggunakan media audio visual. Hasil yang diperoleh pada siklus II terdapat pada tabel berikut:

Tabel 3. Hasil Evaluasi Kognitif Bagian Tumbuhan Siklus II

\begin{tabular}{rlccl}
\hline No. & Nama Siswa & KKM & Nilai & Keterangan \\
\hline 1 & Arfa Yuana Putra & 70 & 60 & Belum Tuntas \\
2 & Aprilia Suci R. & 70 & 80 & Tuntas \\
3 & Ayu Rosalinda & 70 & 80 & Tuntas \\
4 & Banun Maulida & 70 & 70 & Tuntas \\
5 & Biha Zidta Saqina & 70 & 80 & Tuntas \\
6 & Bilqis Safiqa & 70 & 80 & Tuntas \\
7 & Candra Andrea Dhiyaksa & 70 & 90 & Tuntas \\
8 & Fanisya Sya'baniyah & 70 & 70 & Tuntas
\end{tabular}




$\begin{array}{rlrrl}9 & \text { Layyina Qurotun Aini } & 70 & 90 & \text { Tuntas } \\ 10 & \text { Muhammad Bahrul Alam } & 70 & 60 & \text { Belum Tuntas } \\ 11 & \text { Muhammad Ilyas Abdullah } & 70 & 50 & \text { Belum Tuntas } \\ 12 & \text { Najwa Ainun Niswa } & 70 & 80 & \text { Tuntas } \\ 13 & \text { Rossalina Arsyil Al Arifi } & 70 & 80 & \text { Tuntas } \\ 14 & \text { Sekha Nur Rohmah } & 70 & 80 & \text { Tuntas } \\ 15 & \text { Tri Aulia } & 70 & 70 & \text { Tuntas } \\ \text { Rata-rata } & & \mathbf{7 5} & \\ \text { Nilai tertinggi } & & \mathbf{9 0} & \\ \text { Nilai Terendah } & & \mathbf{5 0} & \\ \text { Siswa Tuntas } & & \mathbf{1 3} & \\ \text { Siswa Tidak Tuntas } & & \mathbf{2} & \\ \text { Persentase Ketuntasan } & & \mathbf{8 0 \%} & \end{array}$

Dari tabel di atas, diketahui pada perbaikan pembelajaran siklus II, ada peningkatan hasil yaitu kenaikan ketuntasan belajar dengan KKM 70 naik sebesar $13 \%$ dari semula $67 \%$ menjadi $80 \%$ dan kenaikan rata-rata kelas semula 70 menjadi 75 dengan rentang nilai perolehan sebagai berikut

Tabel 4. Rentang Nilai Hasil Belajar Peserta didik

\begin{tabular}{lll}
\hline Rentang Nilai & Jumlah peserta didik & Persentase (\%) \\
\hline $80-100$ & 9 orang & $60 \%$ \\
$60-79$ & 5 orang & $33,33 \%$ \\
$40-59$ & 1 orang & $6,67 \%$ \\
$<40$ & - & $0 \%$ \\
Jumlah & 15 orang & $100 \%$
\end{tabular}

Dari tabel rentang nilai tersebut diketahui adanya peningkatan perolehan hasil pada interval nilai $80-100$, semula $40 \%$ menjadi $60 \%$ dan pada rentang di bawahnya yaitu $60-79$ turun dari semula $53,33 \%$ menjadi $33,33 \%$ dan masih ada $6,67 \%$ yang ada pada rentang nilai 40-59.

Dapat disimpulkan pada siklus II, tindakan yang diambil guru yaitu penggunaan media audio visual dapat meningkatkan hasil belajar siswa. Sesuai dengan kajian teori Armiza, 2007 bahwa pemahaman konsep adalah kemampuan menangkap pengertianpengertian seperti mampu mengungkapkan suatu materi yang disajikan ke dalam bentuk yang lebih dipahami, mampu memberikan interpretasi dan mampu mengaplikasikannya masuk dalam ranah domain kognitif Bloom kategori C2 tersebut dapat diukur dari hasil evaluasi kognitif. Maka kegiatan evaluasi berupa tes dan hasil yang didapatkan penulis dapat menjadi ukuran pemahaman konsep siswa tentang bagian tumbuhan melalui media audio visual.

Penggunaan media audio visual sendiri memiliki kelebihan seperti yang dikatakan Arsyad (2011: 49-50) dapat melengkapi pengalaman dasar siswa, menggambarkan suatu proses dengan tepat dan berulang-ulang, mengandung nilainilai positif dapat mengundang pemikiran dan pembahasan dalam kelompok siswa, dapat ditunjukkan kepada kelompok besar atau kelompok kecil, kelompok yang 
heterogen maupun homogen maupun perorangan, menampilkan sesuatu yang berbahaya apabila ditampilkan langsung, dan dapat ditampilkan dalam durasi waktu yang lebih efisien. Hal tersebut dapat membantu guru dalam memancing keaktifan belajar siswa dan bagi siswa sendiri dapat meningkatkan motivasi belajar mereka.

\section{SIMPULAN}

Dari penelitian yang telah dilaksanakan pada siklus I dan II, telah diperoleh peningkatan hasil belajar siswa mengenai bagian tumbuhan yang terbukti dengan kenaikan prosentase ketuntasan belajar sebanyak $13 \%$ dan peningaktan capaian hasil pada interval nilai 80-100 sebanyak 20\%. Dari lembar observasi dan catatan di lapangan menunjukkan adanya peningkatan minat belajar dan keaktifan siswa dalam kegiatan pembelajaran daring menggunakan media audio visual. Maka dapat disimpulkan bahwa penggunaan media audio visual dapat meningkatkan pemahaman konsep tentang bagian tumbuhan pada siswa kelas IV SDN 3 Menawan.

\section{DAFTAR PUSTAKA}

Arikunto, S. 2006. Metode Penelitian Kualitatif. Jakarta: Bumi Aksara Arsyad, Azhar. 2011. Media Pembelajaran. Jakarta: PT Raja Grafindo Persada.

Asyhar, Rayanda. 2011. Kreatif Mengembangkan Media Pembelajaran. Jakarta: Gaung Persada (GP) Press Jakarta.

Daryanto. 2014. Penelitian Tindakan Kelas dan Penelitian Tindakan Sekolah Beserta contoh-contohnya. Yogyakarta: Penerbit Gava Media.

Muslimah Miar. 2014. Upaya Peningkatan Pemahaman Konsep Siswa Kelas 5 pada materi FPBdan KPK melalui Learning Tour Management. Jakarta: UIN Syarif Hidayatullah.

Arikunto, Suhardjono, dan Supardi. 2015. Penelitian Pendidikan Kelas. Jakarta: Bumi Aksara

http://file.upi.edu/Direktori/FPMIPA/JUR._PEND._FISIKA/196406061990031MUSLIM/BAHAN_AJAR_MINGGU_KE_3_TAKSONOMI_BLOOM.pdf diakses pada tanggal 20-10-2019 PUKUL 18.30.

http://fisika21.wordpress.com/2012/09/25/kategori-pemahaman-konsep di akses pada tanggal 20-10-2019 PUKUL 18.30. 